\title{
Diversity and Growth Behaviour of Nepenthes (Pitcher Plants) in Tanjung Puting National Park, Central Kalimantan Province
}

\author{
TRI HANDAYANI, DIAN LATIFAH, DODO \\ Plant Conservation Center, Bogor Botanical Garden, Indonesian Institute of Sciences (LIPI), Bogor 16122
}

Received: 6 May 2005. Accepted: 31 July 2005.

\begin{abstract}
Nepenthes is one of the popular genus of pitcher plants. Research on the biodiversity and growth beharviour of Nepenthes spp. in Tanjung Puting National Park was carried out. There were four species studied, namely: $N$. ampullaria, $N$. mirabilis $N$. rafflesiana, and $N$. $x$. hookeriana,. There were about 2096 individuals recorded in this study consisting of $1322 \mathrm{~N}$. ampullaria, 1332 N. mirabilis, $141 \mathrm{~N}$. rafflesiana, and $111 \mathrm{~N}$. x. hookeriana. Variation of tendril positions occurred in 1 rosette plant and 3 climbing stems (mature plants) of $N$. ampullaria, 2 rosettes and 9 mature $N$. mirabilis, 1 rosette and 4 mature $N$. rafflesiana, 2 rosettes and 2 mature $N$. $x$. hookeriana. Their habitats were also very specific. It was noted that 6 species of other plants were grown and associated with the Nepenthes spp.
\end{abstract}

(c) 2005 Jurusan Biologi FMIPA UNS Surakarta

Key words: biodiversity, growth beharviour, Nepenthes ampullaria, Nepenthes mirabilis, Nepenthes rafflesiana, Nepenthes $x$ hokeriana, Tanjung Puting National Park.

\section{INTRODUCTION}

Indonesia is a tropical country that is rich in plant diversity in many areas of forests. Forest is a habitat for various plants which are either determined or undetermined. Many kinds of plants have been used for human life. However still so many plants are not used yet and the potentials remain unrecognised. Amongst the plant diversity, Nepenthes is the most popular pitcher plant. Kalimantan or Borneo has many areas of tropical forests. Nevertheless since the reduction of natural petroleum and local government and the inhabitants turn to find other income in non-petroleum sectors. As a result, many forest areas have been over-exploited. This activity has been uncontrolled and ignored any attempts of rehabilitation for sustainability in the future. This has lead to forest destruction along with habitat disturbance for plant livings.

Nepenthes grows widely throughout Borneo (Phillipps and Lamb, 1996; Clarke, 1997). Unfortunately, land clearing and conversion has caused the habitat lost of many Nepenthes population. This population decrease was also caused by illegal collection by local and foreign collectors for a long time (Phillipps and Lamb, 1996; Clarke, 1997; Cheek and Jebb, 2001; Anon, 2003). Several populations remain in Tanjung Puting National Park, Central Kalimantan Province. This pitcher plant is known as a rare, attractive and unique plant. This plant has "a picher-like organ" on the leaf apex. This organ functions as insect-prey trapper to meet the protein requirement. Nepenthes is classified as rare based on IUCN and WCMC (Cheek and Jebb, 2001). In Indonesia all plants are protected by Peraturan Pemerintah (Government Law) No.7, 1999 about protection and conservation of plant and wildlife (Mogea et al., 2001). -

\footnotetext{
- Alamat korespondensi:

Jl. Ir. H. Juanda 22, Bogor 16122

Tel.: +62-251-322035. Fax.: +62-251-336538.

e-mail: herbogor@indo.net.id
}

Therefore the trade of this plant is controlled internationally under CITES (D'amato, 1998).

In Indonesia Nepenthes has been used by local people for a long time. The stems are used for rope or woven handicrafts. The big pitchers are used for cooking rice and traditional foods (Tamin and Hotta, 1986). The liquid substances inside the pitcher covered by the lid on the peristome are used for healing the eyes sickness, cough, stomach upset, burn injury, skin diseases and stopping urine expelled by children. Besides they are used as decorative plants by exposing the unique of the variation of pitcher shape and color (Danser, 1928; D'amato, 1998; Handayani, 2001; Handayani and Yulia, 2001). Recently Nepenthes has been attractive to researchers to be studied in molecular farming.

According to Jebb and Cheek (1997) and Cheek and Jebb (2001) there are 87 Nepenthes species in the world. Most of them are grown and distributed in Malesian Region. There are only 8 species occurred outside the region: Madagascar (2), Seychelles (1), Sri Lanka (1), India (1), Indochina (6-8), Solomon Archipelago (1), New Caledonia (1), and Australia (1). Jebb and Cheek (1997) reported that the Nepenthes centre of distribution is Indonesia. In Indonesia, most of them occurred in Borneo (approximately 40 species), Sumatra (about 25 species), Java (2 species), Moluccas and Celebes (10 species) and Papua/New Guinea (11 species).

The Tanjung Puting National Park (TPNP) is one of the natural habitats of the pitcher plants in Indonesia. The Park is geographically located between $2^{\circ} 35^{\prime}-3^{\circ} 20^{\prime} \mathrm{S}$ and $111^{\circ} 50^{\prime} \mathrm{E}$. This area is approximately 415.040 ha and bordered by the rivulet of Kumai river, Sekonyer river on the North, Seruyan river on the East, and the coastal areas of Java Sea. Various apexe ecosystems also occurred in TNTP such as lowland tropical forests, heaths, freshwater vegetation, peat vegetation, coastal vegetation and secondary forests. Such conditions allow the pitcher plants to grow well in TPNP. This research aimed to inventory the 
Nepenthes species in TPNP areas. Growth behaviors were recorded.

\section{MATERIALS AND METHODS}

This study site was in forest areas of Tanjung Harapan and Pesalat, Tanjung Puting National Park (TPNP), Central Kalimantan Province, from July to August 2004. The Nepenthes species in TPNP was identified by counting the numbers and observing morphologically the species discovered in each plot. Plots $10 \times 10 \mathrm{~m}^{2}$ was located in randomized design. Well-known species were identified directly in the field and unknown species were collected as herbarium specimens to be identified later. The identification key will be constructed. In addition, the growth behavior was studied. Data collection in the plots constructed in the fields include several variables: tree species associated, the number of leaves per stem of Nepenthes, the number of leaves producing pitchers (fertile leaves), and sterile leaves, the size of pitcher and its parts size, tendril position, and the microclimate.

\section{RESULTS AND DISCUSSIONS}

\section{Diversity of Nepenthes}

In Tanjung Harapan and Pesalat, Tanjung Puting National Park, four Nepenthes species were found: Nepenthes ampullaria, Nepenthes mirabilis, Nepenthes. rafflesiana and Nepenthes $x$ hookeriana. A key of identification has been constructed as follows based on morphological observation:

a. Leaves petiolate

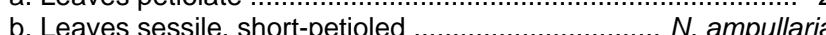

a. The margin of leaves hairy .................................... N. mirabilis.

b. The margin entire …....................................................

a. The peristome elongated into a neck ................... N. rafflesiana.

b. Not an elongated neck at the peristome ......... N. $\quad$. $x$ hookeriana.

\section{Nepenthes ampullaria Jack.}

Stems climbing, up to $8 \mathrm{~m}$ high, slender and smooth. Leaves of the rosettes, very short internodes (almost absent), minute more like tendrils, petiolate, lanceolate, 1-3 $\mathrm{cm}$ long and 0.3-0.7 cm broad, the apex acute. Pitchers of the rosettes dense, oblong, 'pot' like. Tendrils yellowish green, red-brownish red. Pitchers green-yellowish green, green with red or violet spots, $3-8 \mathrm{~cm}$ high, the circumference $5-15 \mathrm{~cm}$. Wings ribbed, $0.3-1.2 \mathrm{~cm}$ broad. Mouth orbicular with periscope extended in the inner part towards the inner part of the mouth, $1.5-4.5 \mathrm{~cm}$ long and 1$4 \mathrm{~cm}$ broad. Peristome $0.7-2 \mathrm{~cm}$ long, green-yellowish green or red to violet-red. Lid spathulate, $1.2-4 \mathrm{~cm}$ long and 0.4-1.5 cm broad, green-purplish red. Leaves of the climbing stems (mature plants), sessile or with a short petiole, lanceolate to spathulate, $10,5-18,0 \mathrm{~cm}$ long and 3,4$5,8 \mathrm{~cm}$ broad. Tendrils 3,4-5,7 long. Lamina surface (adaxial) dark green, abaxial brownish green with delicate hairs. Pitchers of the climbing stems slightly higher and more slender. Tendrils green-brownish green, tendrils 3,4$5,7 \mathrm{~cm}$ long. Pitchers 4,6-5,4 cm high and the circumference $5,8-8,7 \mathrm{~cm}$. Pitchers green, violate-red spotted. Pitchers without wings. Mouth orbicular, 2,1-2,3 cm long and 1,6-1,7 cm broad. Peristome 0,5-0,7 cm broad, green and violet alternately. Lid spatulate, $2-2,1 \mathrm{~cm}$ long and $0,5-0,7 \mathrm{~cm}$ broad, green-purplish red spotted green. The pitcher of $N$. ampullaria was presented in Figure 1.

\section{Nepenthes mirabilis Druce.}

Stems climbing, up to $10 \mathrm{~m}$ high, slender, smooth, thick with prominent internode. Leaves of rosettes sessile, lanceolate rarely ovate, $5-14 \mathrm{~cm}$ long and $1-4 \mathrm{~cm}$ broad, at apex acute, margin with hairs. Tendrils of the rosettes 2,5-7 $\mathrm{cm}$ long, reddish-yellow green. Pitchers of the rosettes bowl-like, narrowly and obliquely ovate in the lower half, cylindrical or somewhat narrowed towards the mouth, brownish-red green, 5,5-8 cm high, the circumference 4-7 $\mathrm{cm}$, with ribs, $0,1-0,3 \mathrm{~cm}$ broad. Mouth nearly round, $1,5-2$ $\mathrm{cm}$ long and $1-1,5 \mathrm{~cm}$ broad. The peristome $0,1-0,2 \mathrm{~cm}$ broad, brownish-red green. The lid orbicular or orbicular ovate, 1-1,8 cm long and 1-1,5 cm broad, purplish-red green. Leaves of the climbing stems petiolate, the length of the petioles $4-10 \mathrm{~cm}$, ovate-lanceolate, $17,5-25 \mathrm{~cm}$ long and $4,5-8 \mathrm{~cm}$ broad, acute at the apex, gradually attenuate into the base, margin entire or with delicate hairs. Tendrils 10-23 $\mathrm{cm}$ long, green-yellowish green. Pitchers more like those of the rosettes, frequently larger than these, $7-17 \mathrm{~cm}$ high, the circumference 3,5-10 cm, green-brownish red, without wings. Mouth oval, $1,2-3,5 \mathrm{~cm}$ long and $0,8-3,5 \mathrm{~cm}$ broad. Peristome 0,1-0,4 cm broad, green-brownish red. Lid orbicular, 1,2-3,5 cm long and 0,8-3,5 cm broad, greenreddish brown. The pitcher of $N$. mirabilis was presented in Figure 2.

\section{Nepenthes rafflesiana Jack.}

Stems climbing, up to $9 \mathrm{~m}$ high, slender, smooth. Leaves of the rosettes petiolate, $4-11 \mathrm{~cm}$ long, green. Lamina lanceolate, $18-38 \mathrm{~cm}$ long and $4-9 \mathrm{~cm}$ broad, acute at the apex, gradually or abruptly attenuate at the base, margin entire, adaxial dark green and abaxial reddish green. Tendrils $10-12 \mathrm{~cm}$ long, yellowish green-reddish green. Pitchers rounded at the base, conical to the top, pale yellow-purplish red spotted green, $8-19 \mathrm{~cm}$ high, the circumference $6-20 \mathrm{~cm}$. Wings ribbed, $0,3-3,5 \mathrm{~cm}$ wide, purplish-spotted green. Mouth oval, narrowed above, 2-6 $\mathrm{cm}$ long and 1,5-5 cm broad. Peristome 0,7-1 cm wide, redpurplish red, with an elongated neck at the peristome and join with the base of the lid. The neck $1,5-3,5 \mathrm{~cm}$ long, redpurplish red. Lid ovate, 2,5-9 cm long, 2-6 cm wide, purplish spotted green. Leaves of climbing stems 7-10,5 cm long, lanceolate, $20-38 \mathrm{~cm}$ long dan lebar $6-11 \mathrm{~cm}$, acute to gradually attenuate at the apex, adaxial green abaxial reddish green. Tendrils $15-40 \mathrm{~cm}$ long, purplish-spotted green. Pitchers infundibulate (funnel-shaped), green with some purple, 17,2-22,5 cm high, the circumference 5,7-13,0 $\mathrm{cm}$, wings absent or if present raised-strip-like shaped. Mouth oval, elongated into a neck up to 6-6,2 cm long, 5$5,2 \mathrm{~cm}$ wide. Peristome 1,2-1,9 cm wide, green with red or violet spotted in very different degres. Neck $3-3,5 \mathrm{~cm}$ long, green and violet alternately. Lid oval, 8-9 cm long and 6-6,2 $\mathrm{cm}$ broad, violet-red spotted green. The pitcher of $N$. rafflesiana was presented in Figure 3.

\section{Nepenthes $\mathrm{x}$ hookeriana Lindl.}

Stems climbing up to $7 \mathrm{~m}$, slender, smooth. Leaves of the rosettes branched, $3-8 \mathrm{~cm}$ long. Lamina lanceolate to spathulate, $5,5-32 \mathrm{~cm}$ long, $2-7 \mathrm{~cm}$ wide, acute to acuminate at the apex, green. Tendrils $3-40 \mathrm{~cm}$ long, green with some violet. Pitchers obliquely urceolate (urn-shaped), green with red to violate-red spots, $7-10 \mathrm{~cm}$ high, the circumference $9-13 \mathrm{~cm}$. Wings ribbed with the ribs $0,5-2 \mathrm{~cm}$ broad, violet-spotted green. Mouth horizontal in front, abruptly incurved towards the lid, $2-4,5 \mathrm{~cm}$ long, 2-4 cm broad. Peristome elongated into a short neck with the outer margin involute, the inner part flat, up to $0,8-1,5 \mathrm{~cm}$ broad, 


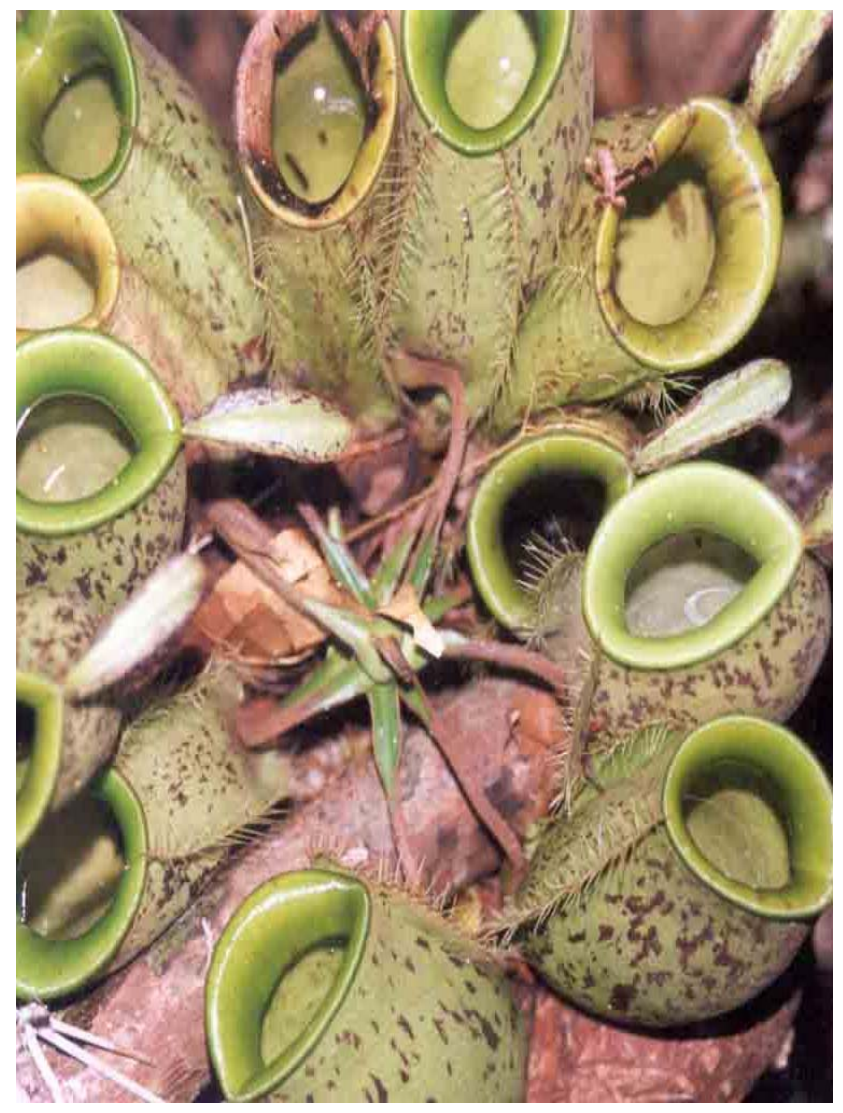

Figure 1. N. ampullaria Jack

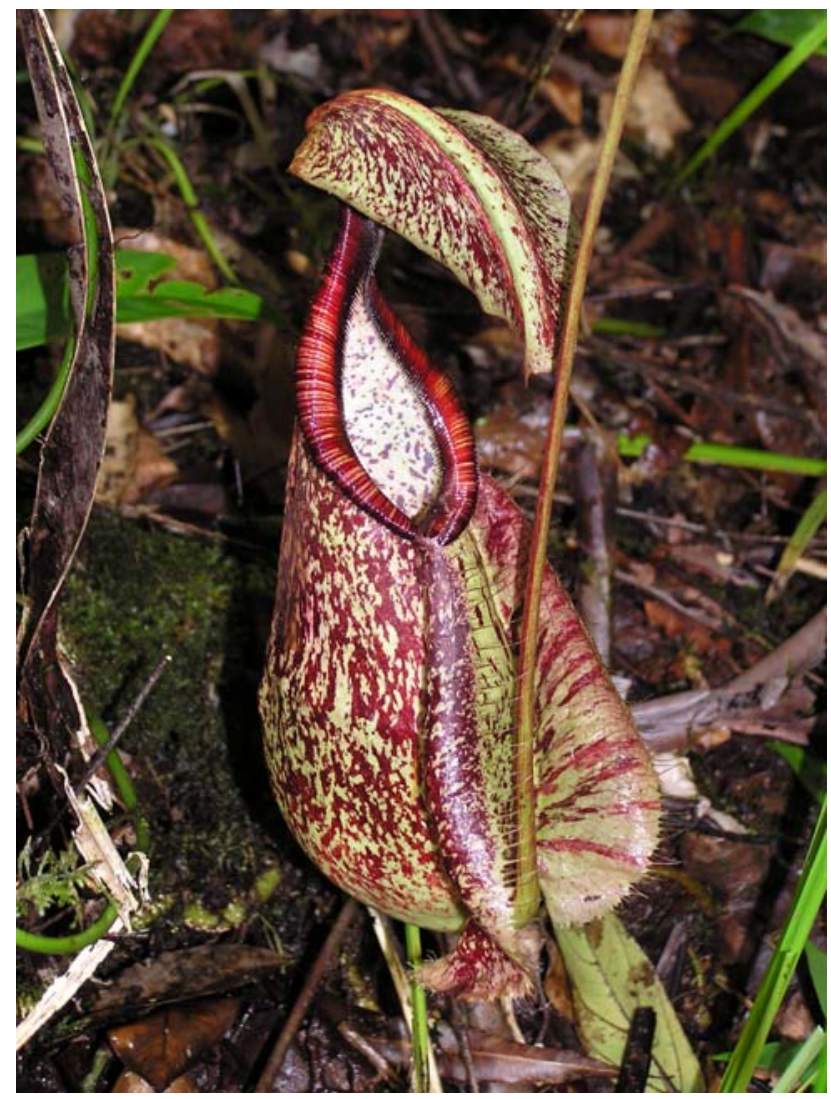

Figure 3. N. rafflesiana Jack.

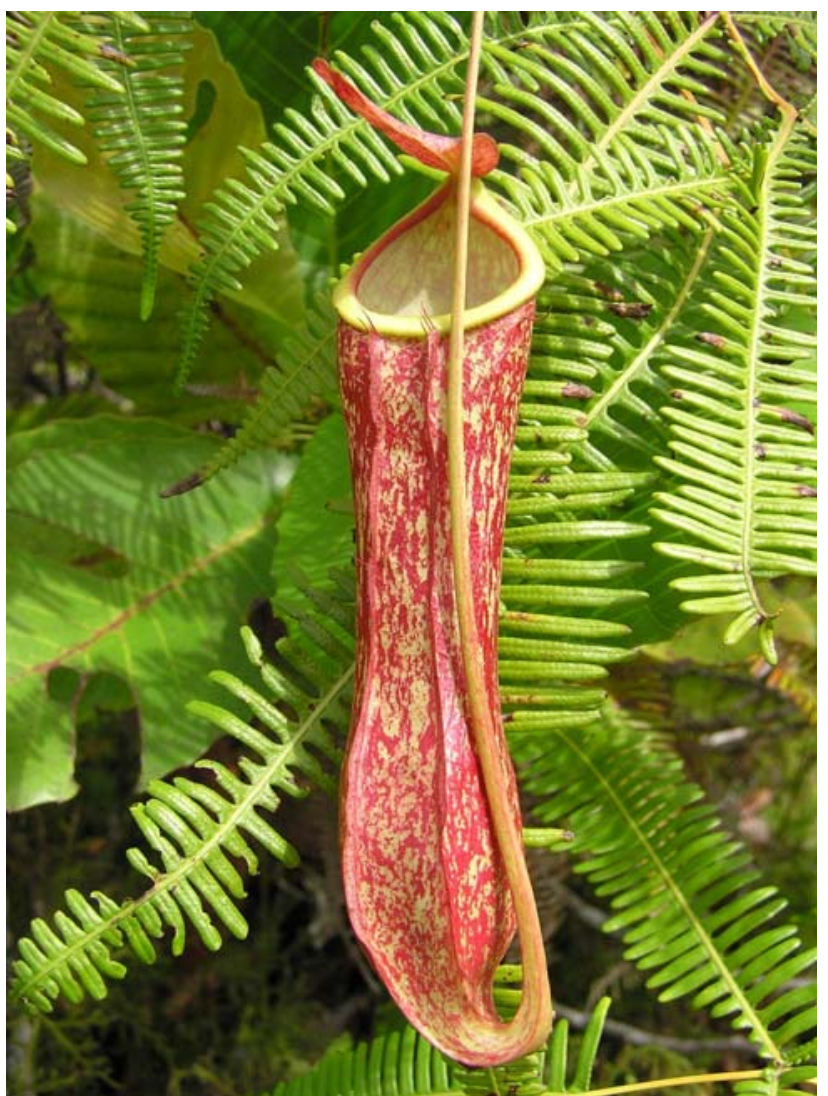

Figure 2. N. mirabilis Druce

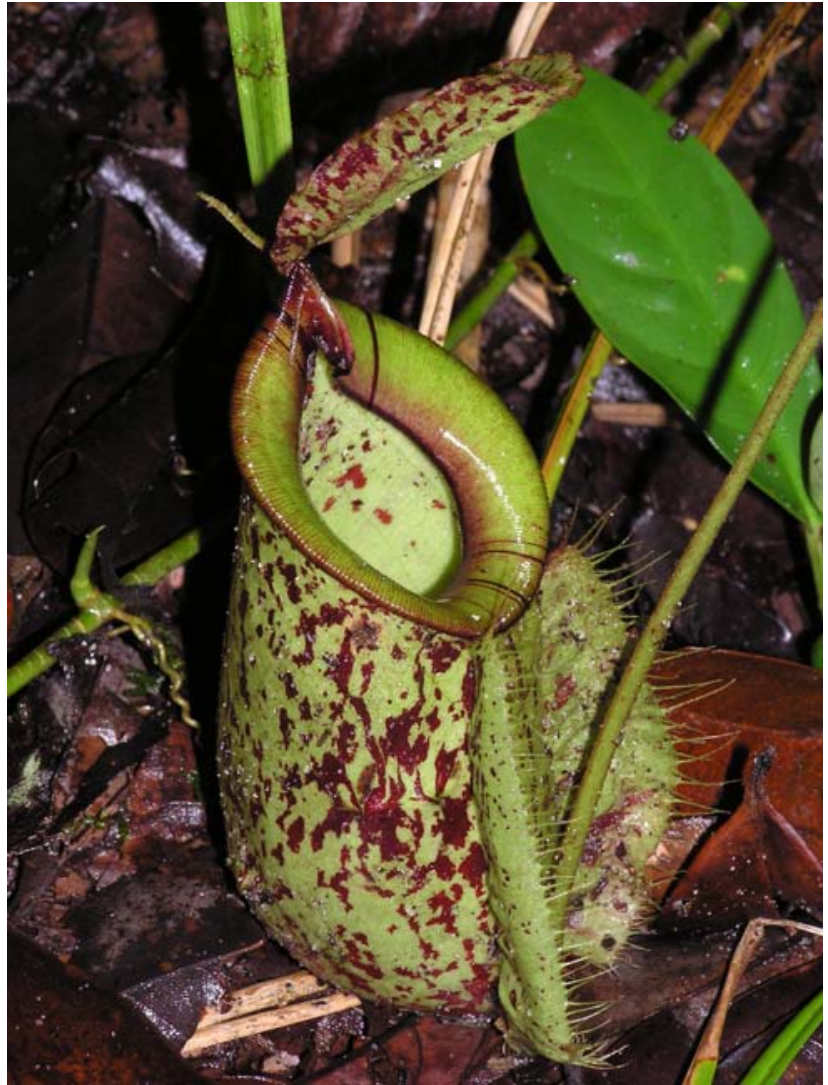

Figure 4. N. x hookeriana Lindl. 
green with violet-red stripped. Lid elliptic-oblong, rounded at the apex, 2-4 cm long, 1,5-2,5 cm broad, red to violet-red spotted. Leaves of the climbing stems branched 3-7 cm long. Lamina lanceolate to spathulate, $19-33 \mathrm{~cm}$ long and 5,2-7 cm wide, acute to acuminate at the apex, adaxial green, abaxial reddish green. Tendrils $14-14,7 \mathrm{~cm}$ long, yellowish green to violet-red. Pitchers infundibulate (funnelshaped), violet-red spotted green, 7,3-11,5 cm high, the circumference $7-10 \mathrm{~cm}$. Wings raised strip-like. Mouth oval berbentuk bulat telur, 3,1-4,5 cm long and 2,5-4 cm wide. Peristome 1-1,7 cm broad, yellowish green with violet-red blotches. Lid elliptic-oblong, rounded at the apex and base, 2,2-4 cm long, 2-4 cm broad, violet-red spotted green. The pitcher of $N$. $x$ hookeriana was presented in Figure 4.

\section{Population number}

The pitcher plant populations were easily found In Tanjung Harapan and Pesalat. In Tanjung Harapan, Nepenthes were found along Beguruh and Feeding Tracks, meanwhile in Pesalat they were found in Tracking and Padang Ilalang Tracks. The number of Nepenthes population in Tanjung Harapan and Pesalat was presented in Table 1.

$N$. mirabilis were the most frequently-found individuals meanwhile the least ones were $N$. $x$ hookeriana. The most

Table 1. Population of Nepenthes spp. in Tanjung Harapan and Pesalat.

\begin{tabular}{|c|c|c|c|c|c|}
\hline \multirow{2}{*}{ Location } & \multicolumn{4}{|c|}{ Species } & \multirow{2}{*}{ Numbe } \\
\hline & N. am & N. mir & N. ra & N. $x$ & \\
\hline \multicolumn{6}{|c|}{ Tanjung Harapan } \\
\hline - Beguruh track & 585 & 273 & 110 & 106 & 1074 \\
\hline $\begin{array}{l}\text { - Feeding track } \\
\text { Pesalat }\end{array}$ & - & 669 & - & - & 669 \\
\hline - Tracking track & 737 & - & 31 & 5 & 773 \\
\hline - Ilalang track & - & 390 & - & - & 390 \\
\hline Number & 1322 & 1332 & 141 & 111 & 2906 \\
\hline
\end{tabular}

Table 2. The number of fertile and sterile leaves and the total in the four Nepenthes spp. in rosette and mature plants.

\begin{tabular}{lllllllll}
\hline Leaves & \multicolumn{2}{c}{$\boldsymbol{N}$. ampularia } & \multicolumn{2}{c}{ N. mirabilis } & \multicolumn{2}{c}{ N. rafflesiana } & \multicolumn{2}{c}{ N.xhookeriana } \\
\cline { 2 - 8 } number & Rosette & Adults & Rosette & Adults & Rosette & Adults & Rosette & Adults \\
\hline Fertile & $0-13$ & $0-11$ & $0-9$ & $0-19$ & $0-6$ & $0-12$ & $0-10$ & $0-14$ \\
Sterile & $1-7$ & $1-33$ & $1-17$ & $1-37$ & $1-17$ & $1-46$ & $1-6$ & $1-19$ \\
Total & $1-13$ & $1-46$ & $1-24$ & $1-40$ & $2-18$ & $4-50$ & $1-10$ & $3-27$ \\
\hline
\end{tabular}

Table 3. Tendril position of Nepenthes sp. in the rosettes and climbing stems.

\begin{tabular}{|c|c|c|c|c|}
\hline Tendril position & N. ampullaria & N. mirabilis & N. rafflesiana & N. $x$ hookeriana \\
\hline Rosettes & & & & \\
\hline F/L/W & $\checkmark$ & $\checkmark$ & $\checkmark$ & $\checkmark$ \\
\hline F/L/Nw & - & - & $\checkmark$ & - \\
\hline $\mathrm{S} / \mathrm{SC} / \mathrm{W}$ & - & $\checkmark$ & - & - \\
\hline \multicolumn{5}{|l|}{$\begin{array}{l}\text { Climbing stems } \\
\text { (mature plants) }\end{array}$} \\
\hline $\mathrm{S} / \mathrm{SC} / \mathrm{V} / \mathrm{S}$ & - & - & $\checkmark$ & - \\
\hline $\mathrm{S} / \mathrm{SC} / \mathrm{V} / \mathrm{Nw}$ & - & - & $\checkmark$ & - \\
\hline $\mathrm{B} / \mathrm{C} / \mathrm{St} / \mathrm{V} / \mathrm{Nw}$ & $\checkmark$ & $\checkmark$ & $\checkmark$ & $\checkmark$ \\
\hline $\mathrm{B} / \mathrm{C} / \mathrm{R} / \mathrm{V} / \mathrm{NW}$ & $\checkmark$ & $\checkmark$ & $\checkmark$ & $\checkmark$ \\
\hline $\mathrm{B} / \mathrm{A} / \mathrm{V} / \mathrm{Nw}$ & $\checkmark$ & - & $\checkmark$ & - \\
\hline F/L/VIS & • & $\bullet$ & $\checkmark$ & $\bullet$ \\
\hline $\mathrm{F} / \mathrm{L} / \mathrm{V} / \mathrm{Nw}$ & $\bullet$ & $\bullet$ & $\checkmark$ & - \\
\hline $\mathrm{B} / \mathrm{C} / \mathrm{St} / \mathrm{G} / \mathrm{Nw}$ & - & - & $\checkmark$ & $\checkmark$ \\
\hline $\mathrm{B} / \mathrm{C} / \mathrm{R} / \mathrm{G} / \mathrm{Nw}$ & - & - & $\checkmark$ & $\checkmark$ \\
\hline
\end{tabular}

Abbreviations: $\mathrm{F}=$ front, $\mathrm{SC}=$ slightly curve, $\mathrm{V}=$ vegetative, $\mathrm{L}=\mathrm{left}, \mathrm{S}=$ side, $\mathrm{St}=$ straight, $\mathrm{G}=$ generative, $\mathrm{R}=$ right, $\mathrm{B}=\mathrm{back}, \mathrm{C}=$ curve, $\mathrm{W}=$ winged, $\mathrm{Nw}=$ not winged. dense populations were found in Beguruh Track i.e. 1074 individuals. In this location, the four Nepenthes grow in group. In this Track, the Nepenthes also prefers various places from shady until open areas, wet to dried and at and $N$. $x$ hookeriana tend to prefer dried and shady areas. On the other hand, $N$. mirabilis was more frequently found in open areas at either wet such as riverside or dried areas. The pitcher plants were found as many as 669 individuals of $N$. mirabilis in Feeding Track. It may be caused by the location of this Track which was undergorbicular. Nevertheless there was one open area which is covered ern Gleichenia linearis (paku resam - Indonesian).

Most areas in Tracking Track in Pesalat were shaded. Jalur tracking. Nepenthes rafflesiana, N. ampullaria, and $N$. $x$ hookeriana grows here which were 773 individuals. Interestingly, $N$. x hookeriana was only found if associated with either $N$. ampullaria or $N$. raffflesiana, because $N . x$ is a hybrid between the parents of these two species (Danser, 1928; Phillipps and Lamb, 1996; D'amato, 1998; Cheek and Jebb, 2001). Furthermore Padang Ilalang e open. The location was originated in burning areas so that Imperata cylindrica (ilalang Indonesian), Melastoma malabathricum and Gleichenia linearis can be found frequently. This land characters are commonly known as an indicator of marginal lands. It is interesting to note that $N$. mirabilis can grow well in this land.

\section{Leaf}

Leaf is very important for Nepenthes to perform photosynthesis and produce protein that comes from digestion zone in the pitcher. Fertile leaves of rosettes in the four species of Nepenthes are more than those of the mature plants. The number of fertile and sterile leaves each stem and the total number of leaves in the study species are presented in Table 2.

From the results above, the rosettes produced more pitchers than the mature plants. This can be related to the function of the pitchers as a prey trapper. The pitchers of the rosettes trap preys (insects) on the gorbicular. It is known that the number of insects living on the gorbicular is more than that of the flying ones. Therefore the rosettes require more pitchers to traps the more insects and vice versa in the mature plants.

\section{Tendrils}

Tendrils are organ which eamanate from the leaf apex and may bear pitchers at their tips in order to stay upright. Tendrils vary in positions and shaps between the rosettes and the mature plants. Apparently this related to the function of the tendrils in bearing the pitchers. Five hundred leaves were observed and the results were presented in observation Table 3.

The tendrils of rosettes of the four species are mostly straight and loop orbicular the front of the pitchers. Meanwhile the tendrils of the mature plants generally turn leftside or rightside and curl backward of the pitcher. The pitchers of the rosettes mostly rest on the orbicular therefore the tendrils does not bear the pitchers much. This is opposite to those of 
the adults plants with aerial pitchers. This influences the strength of the pitchers from the blows of wind. This is also why the tendrils are in contact each other with the other tendrils or with the other branches of other plants.

\section{Pitchers}

The pitchers are produced on the leaf apex and attach on the tendrils. The tendrils themself emanate from the longitudinal veins of primary leaves (Handayani, 2003). The pitchers are the most attractive organ regarding the shape, size and their various colour (Clarke, 1997). This variation is found not only among the same species but also within the different ones. The pitchers which are produced by the rosette are different from the ones produced by mature plants. The shape, size, and colour of the pitchers of $N$. mirabilis are mostly varied, compared by $N$. ampullaria, $N$. rafflesiana, and $N$. $x$ hookeriana. This related to the highest adaptability of $N$. mirabilis in highly variable habitat from shady to open, from river banks to dried areas. The organs produced seemed to be adaptive to the habitat condition. For example, the plants that occurred in shady places produced the longer stems and nodes and the larger leaves. Although the apexes of the plants at vegetative stage are more than the ones of those at the generative stage and vice versa in the plants that grow in open areas.

In all species found in this study, the pitcher shape of the rosette is different front the one of the mature plant. The pitcher shape of the rosette tends to be orbiculared with narrow mouth and the wings attached to it decorated by ribs. Meanwhile in mature plants, the shapes are thinner, the wings are undeveloped, and the mouths are broadr to enable insects to enter. These differences relate to the pitcher function. The thinner shape allows to bear tendrils and pitchers besides become strong from avoiding the blows of the wind. The pitchers of the rosettes trap more preys (insects) on the gorbicular. The insects come into contact with the surfaces of the lids and the top of the pitcher to forage the nectars through the wings. On the other hand, the pitchers of the mature plants catch the flying insects. In this case, the wings are not used as a direction to reach the nectar glands. This leads to the reduction of wing size to be like raised strips.

In TPNP, the pitcher plants grow along river banks, from shady to open areas, $30-40 \mathrm{~m}$ asl, humidity $34-85 \%$, temperatures of $24-46,5^{\circ} \mathrm{C}$, the soil moisture $2-70 \%$, pH 4,5-7,2, litter depth $0-5 \mathrm{~cm}$, canopy coverage $0-70 \%$ and the soil type is sandy clay. The other plants associated are Gleichenia linearis, Imperata cylindrica, Dillenia suffruticosa, Cyperus sp., Melastoma malabathricum, and Syzygium sp.

\section{CONCLUSION}

In Tanjung Harapan National Park and Pesalat there were 4 species of Nepenthes which were $N$. ampullaria, $N$. rafflesiana, $N$. x hookeriana, and $N$. mirabilis. There were 2096 individuals consisting of $1322 \mathrm{~N}$. ampullaria, $141 \mathrm{~N}$. rafflesiana, 111 N. x. hookeriana, and 1332 N. mirabilis. Variation in leave, tendril and pitcher characters was evident. In general, Nepenthes grows in the banks of small rivers, spreading from shady to open places in the study site, $30-40 \mathrm{~m}$ asl, humidity $34-85 \%$, temperatures $24-$ $46,5^{\circ} \mathrm{C}$, soil moisture $2-70 \%, \mathrm{pH} 4,5-7,2$, litter depth $0-5 \mathrm{~cm}$, canopy shade $0-70 \%$ and soil type sandy clay. These four Nepenthes species were associated frequently with 6 species of other plant species which were Gleichenia linearis, Imperata cylindrica,Dillenia suffruticosa, Cyperus $\mathrm{sp}$, Melastoma malabathricum, and Syzygium sp.

\section{REFERENCES}

Anon. 2003. Buku Panduan 41 Taman Nasional di Indonesia. Jakarta: Departemen Kehutanan RI, UNESCO dan CIFOR.

Anon, 2003. IBSAP Dokumen Regional Pemerintah RI. Jakarta: Badan Perencanaan Pembangunan Nasional (BAPPENAS).

Cheek, M and M, Jebb. 2001. Nepenthaceae. Flora Malesiana, Series I, Vol. 15: $13-17$

Clarke, C. 1997. Nepenthes of Borneo. Kota Kinabalu: Natural History Publications (Borneo) Sdn.Bhd.D'amato, P. 1998. The Savage Garden. Berkeley: Ten Speed Press.

Danser, B.H. 1928. The Nepenthaceae of the Netherlands Indies. Bulletine Jardin Botanique de Buitenzorg 3: 330-357.

D'amato, P. 1998. The Savage Garden. Berkeley, CA.: Ten Speed Press.

Handayani, T. 2001. Nepenthes spp. koleksi Kebun Raya Bogor yang berpotensi sebagai tanaman hias. Warta Kebun Raya 3 (1): 26-31.

Handayani, T dan N.D. Yulia. 2001. Potensi pengembangan Nepenthes rafflesiana Jack. sebagai tanaman hias. Prosiding Seminar Hortikultura Kongres Perhorti: 801-608

Handayani, T. 2003. Pertumbuhan dan perkembangan organ kantong pada Nepenthes albomarginata, Nepenthes $x$. hookeriana dan Nepenthes mirabilis di Kebun Raya Bogor. Biosfera 20 (3): 85-92.

Jebb, $M$ and $M$. Cheek. 1997. A Skeletal revision of Nepenthes (Nepenthaceae). Blumea 42 (1): 1-15

Mogea, J.P, D. Gandawijaya, H. Wiriadinata, R.E. Nasution, dan Irawati. 2001. Tumbuhan Langka Indonesia. Bogor: Puslitbang Biologi-LIPI.

Phillipps, A and A. Lamb. 1996. Pitcher-plants of Borneo. Kota Kinabalu: Natural History Publications (Borneo) Sdn.Bhd.

Tamin, R. and M. Hotta. 1986. Nepenthes in Sumatra: The Genus Nepenthes of Sumatra Island. In: Hotta, M. (ed.). Diversity and Dynamics of Plant Life in Sumatra. Kyoto: Kyoto University. 